\title{
Perspective și probleme ale teoriei prototipului ${ }^{\dagger}$
}

\author{
Dirk Geeraerts* \\ Unitatea de Cercetare Lingvistică, Universitatea Catolică din Leuven, Blijde-Inkomststraat 21, PO Box 03308, B-3000 Leuven, Belgia
}

\section{Despre articol}

Istoric:

Primit 5 iunie 2016

Acceptat 13 iunie 2016

Publicat 1 august 2016

Cuvinte-cheie:

cognitive linguistics

\begin{abstract}
Rezumat
În paralel cu cercetările întreprinse asupra aplicării teoriei prototipului la chestiuni privind schimbarea semantică (concretizate, în cele din urmă, în apariția monografiei mele din 1997, Diachronic Prototype Semantics [Semantica diacronică a prototipului]), mi-am îndreptat în cîteva rînduri atenția asupra clarificării teoretice a noțiunii de prototipicitate ca atare (și a noțiunii înrudite de polisemie). În acest articol încerc să introduc o oarecare sistematicitate în multiplele utilizări ale noțiunii de „prototipicitate”, trasând o distincție între două axe de clasificare încrucișată. În primul rînd, disting între două fenomene structurale cruciale ce stau la baza efectelor prototipicității: flexibilitatea (adică absența unor granițe și demarcații precise) și saliența (adică diferențele de dominanță structurală). În al doilea rînd, sugerez că ambele fenomene de prototipicitate pot $f i$ identificate la un nivel intensional (nivelul definițiilor) și la un nivel extensional (nivelul referenților). Clasificarea încrucișată realizată în acord cu cele două axe evidențiază patru tipuri principale de efecte ale prototipicității.
\end{abstract}

\section{Teoria prototipului în lingvistică}

Punctul de plecare în concepția prototipică asupra structurii categoriale este rezumat de afirmația că

în descrierea analitică a categoriilor, cele mai multe tradiții de gîndire au tratat apartenența categorială ca pe un fenomen digital, de tip totul-sau-nimic. Multe studii în filosofie, psihologie, lingvistică și antropologie consideră categoriile drept entități logic delimitate, apartenența la acestea fiind definită printr-un set simplu de trăsături criteriale ale fiecărei unități, şi în care toate elementele ce posedă respectivele atribute criteriale au grad deplin şi egal de apartenență. Cu toate acestea, s-a susținut recent ... că unele categorii naturale sunt analogice și trebuie reprezentate logic într-o manieră care să reflecte structura lor analogică (Rosch, 1975, p. 573-574).

După cum vom vedea în Secțiunea 2, definiția exactă a noțiunii de prototipicitate așa cum este ea utilizată în lingvistică nu este lipsită de dificultăți. Pentru început, vom realiza o scurtă prezentare a stadiului actual de dezvoltare a teoriei prototipului în lingvistică ${ }^{1}$.

Teoria a luat naștere la mijlocul anilor 1970 prin cercetările întreprinse de Eleanor Rosch asupra structurii interne a categoriilor (sinteze pot fi găsite în Rosch, 1978, 1988 și în Mervis \& Rosch, 1981; studiul de bază este prezentat mai ales în Heider, 1972; Rosch, 1973, 1975, 1977; Rosch \& Mervis, 1975; Rosch et al., 1976a,b). De la originile sale psiholingvistice, teoria prototipului s-a dezvoltat îndeosebi ${ }^{2}$ iîn două

\footnotetext{
†Apărut iniţial în „Linguistics”, vol. 27, nr. 4, p. 587-612, 1989, Crossref. Republicat în Words and Other Wonders, 2006, p. 3-26, Crossref.

*Adresă de corespondență: dirk.geeraerts@arts.kuleuven.be.

${ }^{1}$ Discuția din Secțiunea 2 va permite înțelegerea faptului că sintagma teoria prototipului ar trebui utilizată cu grijă, din moment ce uniformitatea teoretică pe care o sugerează tinde să anuleze distincțiile reale dintre diversele forme ale prototipicității discutate în literatura de specialitate. Sintagma menționată este întrebuințată în acest studiu doar ca element convenţional de referință, pentru a denumi mai multe concepții teoretice înrudite privind structura categorială, care împărtășesc axarea asupra unuia sau mai multora dintre diferitele tipuri de efecte ale prototipicităţii discutate în Secțiunea 2.

${ }^{2}$ Deși nu exclusiv: a se vedea Rosch (1988, p. 386).
} 
direcții. Pe de o parte, concluziile și propunerile avansate de Rosch au fost adoptate în psiholexicologia formală (şi, mai general, în psihologia procesării informației), interesată de modele formale pentru memoria conceptuală umană și operațiile acesteia, fiind astfel învecinată cu domeniul inteligenței artificiale. Prezentări excelente ale aspectelor reprezentaționale și experimentale aflate în joc sînt Smith \& Medin (1981) și Medin \& Smith (1984), iar o mostră interesantă din cercetările actuale poate fi descoperită în Neisser (1987). Pe de altă parte, încă de la începutul anilor 1980, teoria prototipului a avut din ce în ce mai mult succes în lingvistică, fapt dovedit de numeroase monografii și volume colective în care teoria prototipului și extensiunile cognitive ale acesteia au un rol important (Wierzbicka, 1985; Lakoff, 1987; Langacker, 1987; Craig, 1986; Holland \& Quinn, 1987; Rudzka-Ostyn, 1988; Lehmann, 1988; Hüllen \& Schulze, 1988; Tsohatzidis, 1989; Taylor, 1989). Aceste noi dezvoltări fac obiectul studiului nostru.

Pe fondul dezvoltării semanticii lingvistice, teoria prototipului poate fi definită în primul rînd în contrast cu modelul componențial de analiză semantică de uz comun în gramatica transformațională și stereotipic asociat cu analiza lui Katz \& Fodor asupra engl. bachelor „burlac” (1963); într-un prim studiu de susținere a abordării prototipice, Fillmore (1975) a numit această teorie semantică teoria listei de inventar (engl. check-list theory of meaning). Reacția adepților prototipicităţii împotriva acestei abordări semice a avut, totuşi, efectul colateral negativ de a crea impresia că teoriile prototipului au respins orice tip de analiză componențială, însă aceasta este o neînțelegere pentru simplul motiv că nu poate exista descriere semantică lipsită de o analiză prin descompunere. Ca instrument euristic în descrierea și comparația sensurilor lexicale, analiza componențială iș̦i păstrează validitatea (de fapt, aceasta nu și-a dobândit valoarea odată cu apariția analizei componențiale ca teorie semantică explicită, ci le fusese evidentă lexicografilor încă din vremuri străvechi). Mai degrabă, dificultăţile modelului neostructuralist de analiză semică dezvoltat prin teoria structuralistă a cîmpului lexical sunt de altă natură; nu utilizarea descompunerii ca instrument descriptiv creează tensiuni, ci statutul atribuit analizei semice, astfel că două aspecte importante trebuie menționate.

În primul rînd, aşa cum sugerează citatul de la începutul acestei introduceri, definiţiile semice sînt prin tradiție percepute ca fiind criteriale, adică seturi de atribute enumerabile indispensabile pentru definirea noțiunii în discuție și care, luate împreună, sînt suficiente pentru a delimita respectiva noțiune de toate celelalte. În schimb, teoria prototipului susține că nu trebuie să existe un singur set de atribute definitorii care să se conformeze condiției de necesitate-și-suficiență $\breve{a}^{3}$.

În al doilea rînd, adepții teoriei prototipului se opun ideii că există în limbile naturale o structură semantică autonomă ce poate fi studiată ca atare, fără a ține seamă de celelalte capacități cognitive ale ființei umane. Mai exact, faptele semantice din limbile naturale nu pot fi studiate separat de cunoașterea enciclopedică pe care indivizii o posedă; tocmai ipoteza că există o structură pur lingvistică a opozițiilor semantice permite semanticii de tip structuralist și neostructuralist să postuleze existența unei distincții între cunoașterea semantică şi cunoașterea enciclopedică. Teoria prototipului tinde să minimalizeze distincția în primul rînd din raţiuni metodologice: întrucît categorizarea lingvistică este un fenomen cognitiv întocmai ca celelalte capacităţi cognitive ale omului, este important ca ea să fie studiată în relație cu aceste alte capacității. Au fost formulate și argumente mai concrete pentru a demonstra că distincția dintre un nivel enciclopedic și un nivel semantic al structurii categoriale nu se susține ${ }^{4}$. De exemplu, dat fiind că extensibilitatea flexibilă a conceptelor prototipice este o caracteristică sincronică a structurii lingvistice și dat fiind că aceste extensii se pot baza aleatoriu pe trăsături aşa-zis enciclopedice sau așa-zis semantice, distincția dintre ambele tipuri de informație își pierde relevanța sincronică. Să considerăm cazul metaforei: înainte ca leu să dobîndească sensul de „om curajos”, trăsătura „curajos” nu este distinctivă din punct de vedere structural în interiorul structurii semasiologice a lui leu și, ca atare, ea trebuie să fie considerată enciclopedică potrivit teoriilor structuraliste. Dar dacă se poate accepta (și acesta este, desigur, punctul

\footnotetext{
${ }^{3}$ Trebuie observat că acest argument se aplică la fel de bine și formelor axiomatice de descriere, bazate pe postulat, care s-au dezvoltat ca principală alternativă reprezentațională la analiza componențială katziană. Noțiunea de criterialitate este tot atît de mult parte esențială din versiunile clasice ale alternativei axiomatice pe cît este din analiza semică katziană.

${ }^{4}$ A se vedea, printre alții, Haimann (1980) și Geeraerts (1985b).
} 
decisiv) că extensia metaforică a lui leu către noțiunea „om curajos” nu este doar o chestiune de variație diacronică, ci este pur și simplu un efect al flexibilităţii sincronice a unităţilor lexicale, trăsătura capătă în mod clar statut semantic. Dacă, mai mult decît atît, argumentul se poate repeta în sensul că astfel de extensii metaforice sincronice se pot baza pe orice atribut presupus enciclopedic, distincția de ansamblu între concepte semantice și enciclopedice nu are temei ${ }^{5}$.

Fără îndoială, problema nu poate fi clarificată aici. În intenția noastră, ceea ce prezintă importanță este mai degrabă de a vedea ce obiecții ridică teoria prototipului față de teoriile componenţiale de tip katzian. Mai întîi, se sugerează că noțiunile lexicale sînt criteriale în sens clasic și, mai apoi, se sugerează că există un nivel pur lingvistic al structurării conceptuale, clar separat de alte forme „enciclopedice” de informație conceptuală și care poate fi astfel studiat în mod autonom, prin izolarea metodologică faţă de alte tipuri de explorare cognitivă. Spre deosebire de aceste puncte de vedere, teoria prototipului susține o concepție non-criterială asupra structurii categoriale şi o perspectivă metodologică interdisciplinară care ia în considerare studii relevante din cadrul altor științe cognitive. (Chiar transferul abordării prototipice din psihologia experimentală în lingvistică reflectă această atitudine).

În mod evident, această poziționare istorică a teoriei prototipului cu privire la predecesorii săi imediați din domeniul semanticii lexicale în mod clar nu explică de ce aceasta s-a dovedit a fi o alternativă atît de înfloritoare. De ce abordarea prototipică a atras (și atrage) o bună parte a comunității lingvistice? Pe de o parte, dezvoltarea istorică a gramaticii generative a dus la creșterea considerabilă a interesului acordat problemelor de semantică. De fapt, nu ar trebui uitat că abia după încorporarea unei componente semantice în tiparul transformațional chomskianismul a dobîndit popularitate internațională; atractivitatea de ansamblu a teoriei generative standard s-a datorat fie și în parte potențialului furnizat de componenta semantică katziană. Pe de altă parte, promisiunile nu s-au împlinit. În cadrul paradigmei generative, semantica generativă (care a întruchipat cu cea mai mare intensitate abordarea semantică) a slăbit în fața sintaxei autonome, în care semantica abia dacă a jucat un rol demn de atenție. În afara abordării generativiste, semantica formală de tip montagovian era prea strict limitată la sensul propozițional pentru a păstra atenția celor interesaţi cu precădere de structura internă a categoriilor limbii naturale (și nu în primul rînd de modul în care aceste categorii se combină în unități mai ample) ${ }^{6}$. Pe scurt, în ceea ce privește semantica, pe piaţa ideilor lingvistice de la începutul anilor 1980 exista o falie care nu a putut fi acoperită de principalele tendinţe ale vremii ${ }^{7}$.

$\mathrm{Cu}$ toate acestea, recunoașterea faptului că exista un anume interes în semantica categoriilor limbii naturale la care teoria prototipului a putut apela nu spune totul. De ce oamenii nu au aderat pur şi simplu la teoria componențială popularizată de Katz, sau la metoda concurentă de reprezentare axiomatică, deși acestea s-au îndepărtat treptat de centrul de interes al lingvisticii pe măsură ce sintaxa autonomă şi semantica formală au preluat controlul? În general, există o serie de așteptări metodologice pe care oamenii

\footnotetext{
${ }^{5}$ Distincția între concepte semantice și enciclopedice împotriva căreia reacționează semantica cognitivă este adesea greșit interpretată. Mai exact, în afirmația că nu există o deosebire de principiu între informația semantică și cea enciclopedică, cuvintele semantic și enciclopedic nu sunt utilizate (așa cum sugerează Lehmann, 1988) cu sensurile de „așa cum poate fi întîlnit în dicționare” și, respectiv, „așa cum poate fi întîlnit în enciclopedii”. Mai degrabă, distincția respinsă se referă la o presupusă deosebire existentă în memoria conceptuală a vorbitorului unei anumite limbi; aceasta implică presupunerea că există un nivel independent de informație semantică aparținînd limbii, diferit de cunoașterea pe care un individ o are asupra lumii. Informațiile incluse în mod obişnuit în enciclopedii sînt date științifice de tipul „ovulație declanșată de copulație” folosite pentru a defini cuvântul pisică (exemplul îi aparține lui Lehmann); cu toate acestea, în timp ce distincția dintre cunoașterea științifică și cea a unui nespecialist este în primul rînd de ordin social, acest tip de informaţie enciclopedică este relevant pentru perspectiva psihologică a semanticii cognitive doar dacă vocabularul individual ce trebuie descris este cel al unei persoane ce deține un anumit volum de cunoștințe științifice despre pisici (sau dacă, prin idealizare sociolingvistică, vocabularul vorbitorului de rând ar conține acea informație științifică).

${ }^{6}$ Există, desigur, excepții precum Dowty (1979) care confirmă regula. Schița istorică a apariției teoriei prototipului oferită aici este tratată mult mai amănunțit în Geeraerts (1988b).

${ }^{7}$ Întrucît preocupările de semantică ale reprezentanților semanticii generative nu au mai fost incluse pe agenda teoriilor dominante ale vremii, nu mai surprinde pe nimeni că George Lakoff, unul dintre cei mai importanți specialiști în semantică generativă este, pe de altă parte, considerat unul dintre principalii cognitiviști.
} 
din ziua de astăzi le au din partea teoriilor lingvistice: capacitate descriptivă (în special sub forma unui larg orizont empiric), profunzime explicativă, productivitate și formalizare. Deși teoria prototipului se clasează mult mai jos în ierarhia formalizării decît abordarea axiomatică sau cea caracterială, avantajele pe care le oferă în privința celorlalte trei aspecte sunt considerabile.

În primul rînd, aceasta tratează o serie de fapte semantice care au fost ignorate de abordările cu profil structural. Granițele neclare dintre categoriile lexicale, existența gradelor de tipicitate pentru membrii unei categorii, natura flexibilă și dinamică a sensurilor cuvintelor, importanța metaforei și metonimiei ca bază a flexibilității, toate acestea sînt elemente de conținut ale semanticii, percepute în mod intuitiv, care au fost în bună măsură neglijate de semantica structurală. Este adevărat că ele au fost uneori evidenţiate ca aspect indispensabil al oricărei teorii semantice complete: gîndiți-vă, de pildă, la remarca lui Weinreich (1966, p. 471) potrivit căruia o teorie semantică ar trebui să se poată ocupa de „deviația interpretabilă” sau la pledoaria lui Uhlenbeck (1967) pentru o concepție dinamică asupra sensurilor cuvintelor ${ }^{8}$. Totuși, aceste comentarii nu au avut ca urmare închegarea unei teorii. Mai exact, doar odată cu apariția teoriei prototipului lingvistica contemporană a dezvoltat un model valid de explicare a polisemiei unităților lexicale. Aceasta este probabil cea mai atractivă caracteristică a teoriei prototipului: iată în cele din urmă o abordare descriptivă a sensului lexical în care intuițiile noastre preteoretice despre capacitatea de ierarhizare, neclaritate, flexibilitate și despre gruparea sensurilor primesc atenția cuvenită.

În al doilea rînd, teoria prototipului pare să fie o teorie productivă nu doar în sensul că observațiile sale cu privire la categoriile lexicale pot fi cu ușurință aplicate în diverse arii ale lexicului, ci și în sensul că poate fi extinsă către alte aspecte ale lingvisticii. Dacă teoria prototipului a început prin a da randament din punct de vedere descriptiv în semantica lexicală, în scurt timp ea a devenit rodnică și din punct de vedere teoretic, în sensul că și alte zone ale lingvisticii au fost luate în considerare. Cîteva exemple recente de asemenea dezvoltări ar fi de ajuns: fonologie (Nathan, 1986), morfologie (Bybee \& Moder, 1983; Post, 1986), sintaxă (van Oosten, 1986; Ross, 1987), lingvistică istorică (Winters, 1987; Aijmer, 1985), teoria marcării (van Langendonck, 1986), lexicografie teoretică (Geeraerts, 1985c). Prin aceste extinderi și altele asemenea ${ }^{9}$, teoria prototipului a devenit una din pietrele de temelie ale lingvisticii cognitive care încearcă să explice interacțiunea dintre limbă și cogniție la toate nivelele structurii lingvistice: nu trebuie decît să observăm rolul principal acordat de Langacker, 1987) (una dintre lucrările fundamentale în lingvistica cognitivă) concepției prototipice asupra structurii categoriale pentru a-i înțelege importanța ${ }^{10}$. În acest sens, dezvoltarea teoriei prototipului într-o lingvistică cognitivă are potențialul captivant al unei teorii cognitive unificate asupra categorizării lingvistice.

În al treilea rînd, profunzimea explicativă a teoriei prototipului rezidă parțial în tendința spre generalizare și în natura sa interdisciplinară. Importanța legăturii sale genetice cu psiholingvistica poate fi pe deplin înțeleasă doar pe fondul exigențelor chomskiene privind teoriile gramaticale. Metodologia lui Chomsky se află, de fapt, în poziția stranie de a declara lingvistica drept o știință cognitivă, dar de a refuza

\footnotetext{
${ }^{8}$ Aceste antecedente nu sînt singurele care ar putea fi menționate. Am atras atenția în altă parte (1988c) asupra asemănărilor dintre tradiția istorică, prestructuralistă a cercetărilor de semantică și semantica cognitivă actuală, însă există alte tradiții (nu dominante, e adevărat) ale cercetării semantice cu care semantica cognitivă se relaționează metodologic: gîndiți-vă, de exemplu, la studiile antropologice ale lui Malinowski, Firth și, în general, la Școala de la Londra. Pînă și un structuralist ca Reichling a exprimat opinii privind structura polisemiei care se apropie de punctul de vedere al teoriei prototipului: lucrarea sa importantă despre cuvînt ca unitatea fundamentală a lingvisticii (1935) conține o analiză a cuvîntului danez spel, care este neobișnuit de asemănătoare cu observațiile lui Wittgenstein despre echivalentul german Spiel. Ideea care trebuie reliefată este următoarea: ca teorie despre structura (radială, grupată, flexibilă a) polisemiei, teoria prototipului reprezintă în mare măsură redescoperirea opiniilor care au fost primordiale în epoca prestructuralistă a dezvoltării semanticii lexicale și care au supraviețuit ascunse în etapa structuralistă și în cea transformaționalistă.

${ }^{9}$ Prin orizontul lor larg, abordarea funcționalistă a lui Seiler (1986) și abordarea naturalistă a lui ? sunt interesante mai ales pentru utilizarea prototipicității cu privire la diferite aspecte ale organizării formale a limbii.

${ }^{10} \mathrm{O}$ bibliografie a studiilor din domeniul lingvisticii cognitive se găsește în Dirven (1988). Merită menționat faptul că lingvistica cognitivă se află actualmente (la începutul anilor 1990 - n.tr.) într-un stadiu de organizare: o primă conferință internațională de lingvistică Cognitivă s-a ținut la Duisburg în martie 1989, iar o nouă revistă intitulată „Lingvistica Cognitivă”, publicată de Mouton, este programată să înceapă să apară la începutul anului 1990.
} 
să se ocupe în mod direct de descoperirile celorlalte științe ale minții. Altfel spus, lingvistica chomskiană pretinde că dezvăluie ceva despre minte, dar recurge cu obstinație la o metodologie strict autonomă în detrimentul dialogului deschis cu psihologia, care ar părea să fie direct implicată într-o astfel de supoziție. Pe de altă parte, valorificarea în lingvistică a descoperirilor din psiholingvistică, fapt propriu teoriei prototipului, duce idealul chomskian al profunzimii explicative în plan cognitiv la consecințele sale naturale, adică la abandonarea autonomiei metodologice a lingvisticii în favoarea unui dialog interdisciplinar cu celelalte științe cognitive ${ }^{11}$. Prin deschiderea sa interdisciplinară, teoria prototipului ia în serios supozițiile cognitive ale chomskianismului. Aceasta devine cu atît mai importantă într-un moment în care știința cognitivă se conturează ca îmbinare interdisciplinară între psihologie, neuroștiință, inteligență artificială și filozofie. Este probabil una din rațiunile pentru care teoria prototipului urmărește, prin raporturile sale interdisciplinare, să racordeze lingvistica la cel mai semnificativ progres pe care științele umane îl cunosc în momentul de față.

\section{Probleme de definire, prima serie: „Prototip” ca noțiune prototipică}

Atractivitatea teoriei prototipului nu ar trebui, totuși, să ascundă faptul că definiția exactă a prototipicității nu e lipsită de controverse. Scopul acestei secțiuni (și al celei următoare) este acela de a analiza sursele confuziei, făcînd înțeles faptul că prototipicitatea este ea însăși, cum spune Posner (1986), un concept prototipic. Ca un prim pas, vom arunca o privire asupra a patru caracteristici frecvent menționate (în diverse combinații) ca fiind specifice prototipicității. În fiecare caz, un citat din primele studii asupra prototipului este adăugat pentru a ilustra ideea.

(i) Categoriile prototipice nu pot fi definite prin intermediul unui singur set de atribute criteriale (necesare și suficiente):

Am arătat că multe cuvinte... au ca sens nu o listă de condiții necesare și suficiente pe care un lucru sau un fapt trebuie să le îndeplinească pentru a se număra printre membrii categoriei indicate de cuvînt, ci mai degrabă un obiect psihic sau un proces psihologic pe care l-am numit prototip (Coleman \& Kay, 1981, p. 43).

(ii) Categoriile prototipice au o structură determinată de asemănarea de familie sau, mai general, structura lor semantică ia forma unui set radial de sensuri grupate și suprapuse ${ }^{12}$ :

Scopul studiului de față a fost acela de a explora unul dintre principiile structurale majore, care, credem noi, poate dirija formarea structurii prototipice a categoriilor semantice. Acest principiu a fost sugerat pentru prima dată în filozofie; Wittgenstein (1953) a susținut că referenții unui cuvînt nu trebuie să aibă elemente comune pentru ca acesta să fie înțeles și utilizat în funcționarea normală a limbii. El a sugerat că, mai degrabă, o asemănare de familie poate fi ceea ce a unit diverșii referenți ai unui cuvînt. O relaţie de asemănare între elemente ia forma $\mathrm{AB}, \mathrm{BC}, \mathrm{CD}, \mathrm{DE}$. Adică, fiecare unitate are cel puțin un element, sau, probabil, mai multe, în comun cu una sau mai multe unităţi, dar nici un element, sau doar cîteva, în comun cu toate unitățile (Rosch, 1975, p. 574-575).

\footnotetext{
${ }^{11}$ Pe lângă legătura cu psiholingvistica, există și o relație cu cercetările de inteligență artificială, prin corespondențele dintre noțiunea de prototipicitate și cea de cadru; a se vedea Fillmore (1977). Trebuie, totuși, subliniat că legătura este relativ slabă; în mod specific, corespondența menționată este într-o oarecare măsură contrabalansată de critica lui Lakoff (1987) asupra ipotezelor cercetărilor de prim rang privind inteligența artificială (dar, din nou, unul din studiile actuale ale lui Lakoff include o abordare conectivistă a modelării formale a unor noțiuni de semantică cognitivă, precum schemele imagistice metaforice). În general, organizarea relației dintre semantica cognitivă și știința cognitivă orientată spre inteligența artificială va reprezenta una dintre sarcinile majore pentru dezvoltarea ulterioară a semanticii cognitive.

${ }^{12}$ A se vedea Lakoff (1987, Capitolul 6) pentru noțiunea de set radial și Givón (1986) pentru o comparație între viziunile lui Wittgenstein și cele ale teoriei prototipului. Acentul pe care Givón îl pune pe deosebirile dintre cele două este ușor exagerat, întrucît tinde să pună în umbră respingerea comună a așa-numitei teorii clasice. A se vedea și nota următoare.
} 
(iii) Categoriile prototipice au grade de apartenență categorială; nu toți membrii sînt în mod egal reprezentativi pentru o categorie:

Prin prototipuri ale categoriilor ne-am referit în general la cele mai clare cazuri de apartenență categorială, definite operațional prin judecata oamenilor cu privire la valoarea apartenenței la respectiva categorie... putem judeca în ce măsură ceva reprezintă un caz clar şi ne putem ocupa de categorii pe baza cazurilor clare, în absența totală a informațiilor referitoare la limite (Rosch, 1978, p. 36).

(iv) Categoriile prototipice au granițe neclare:

Noile tendințe în studiul categorizării au supus investigației și dezbaterii cîteva dintre chestiunile majore ale înțelegerii și învățării, a căror soluționare a rămas fără răspuns în abordările anterioare. Concluziile empirice au stabilit că ... limitele categoriilor nu sînt în mod necesar clar delimitate (Mervis \& Rosch, 1981, p. 109).

Ca o primă remarcă privind aceste caracteristici, ar trebui observat că ele nu sunt singurele ce pot fi utilizate în încercările de a defini concepția prototipică asupra categorizării. Ar trebui menționate două clase de asemenea trăsături adiționale.

Există, pe de o parte, caracteristici ce nu corespund (precum cele patru de mai sus) structurii categoriilor, ci care privesc mai degrabă trăsăturile epistemologice ale așa-numitelor categorii non-aristotelice ${ }^{13}$. De exemplu, opinia conform căreia categoriile prototipice nu sunt, prin natura lor, „obiectiviste”, ci „experiențialiste" (Lakoff, 1987), prevede mai curînd relația epistemologică dintre concepte şi lume decît proprietăţile structurale ale acelor concepte. Mai precis, aceasta avansează o comparație a opiniei aşa-zis clasice, conform căreia „categoriile minții... sunt pur și simplu reflecții ale categoriilor care se presupune că există în mod obiectiv în lume, independent de toate ființele” cu opinia că „atît categoriile cognitive, cît și rațiunea umană depind de aspectele experiențiale ale psihologiei umane" (Lakoff, 1982, p. 99). O astfel de caracterizare mai degrabă epistemologică decît structurală a conceptelor naturale presupune și un aspect metodologic; ea reclamă că nici o categorie prototipică nu ar trebui studiată în afara contextului ei experiențial. Deși o asemenea concepție epistemologică sau metodologică asupra categorizării prototipice este extrem de valoroasă, în paginile următoare vom adopta un punct de vedere structuralist; vom încerca să decidem dacă este posibil să oferim o caracterizare coerentă, structural intrinsecă a categoriilor prototipice.

Pe de altă parte, există proprietăți structurale ale conceptelor prototipice care pot fi reduse la cele patru trăsături de bază menționate mai sus. De exemplu, chiar în propriile studii asupra categorizării prototipice am evidențiat în mod repetat flexibilitatea conceptelor prototipice $(1983,1985$ a), alături de faptul că o distincție între componentele semantice și enciclopedice ale conceptelor lexicale nu poate fi susţinută în cazul conceptelor prototipice (1985b). Dar flexibilitatea categoriilor prototipice este asociată în mod direct cu cea de-a patra caracteristică: incertitudinile referitoare la granițele denotaționale al unei categorii

\footnotetext{
${ }^{13}$ Forma „așa-numitelor” accentuează, mai întîi, că concepția lui Aristotel se pot identifica aspecte care corespund mai degrabă abordării cognitiviste decît celei clasice și, în al doilea rînd (mai general), că poziția filosofică a teoriei prototipului are nevoie de mai multe clarificări. Situația actuală (1989 - n.tr.) este mai degrabă confuză: în timp ce poziția roschiană de tip clasic caracterizează teoria prototipului ca non-aristotelică și wittgensteiniană, Givón (1986) a susținut că teoria prototipului este non-wittgensteiniană (vezi nota anterioară), dar în timp ce Givón mai consideră că teoria prototipului e și non-platoniciană, Wierzbicka (la care vom reveni în secțiunea a treia) prezintă cu acuratețe o versiune explicit platoniciană a teoriei prototipului. În linii mai mari, poziția filosofică a teoriei prototipului a fost discutată pînă acum mai ales pe fondul filosofiei clasice (Aristotel și Platon) și pe fondul filosofiei analitice contemporane (vezi Lakoff, 1987). Aceasta înseamnă că o mare parte a istoriei filosofiei occidentale este trecută sub tăcere; este regretabil, întrucît perioada post-carteziană din istoria filosofiei se ocupă cu problemele epistemologice de imediat interes pentru semantica cognitivă. Mai exact, dacă se poate accepta că unul dintre aspectele epistemologice majore ale unei concepții prototipice asupra structurii categoriale constă în faptul că categoriile sunt scheme interpretative utilizate în mod flexibil și dinamic în relațiile noastre cu realitatea, un reper filosofic important pentru teoria prototipului e de aflat în acele teorii filosofice care recunosc rolul constitutiv al cunoștințelor existente în raport cu situațiile noi. Așa cum am susținut în cu alt prilej (1985b), mișcarea fenomenologică husserliană (așa cum este reprezentată, în mod caracteristic, de Maurice Merleau-Ponty) oferă un bun punct de plecare pentru o confruntare ulterioră cu filosofia.
} 
sugerează că aceasta nu trebuie utilizată neapărat într-o manieră inflexibilă. În mod similar, absența unei demarcaţii clare între informația enciclopedică și cea pur semantică decurge chiar din această flexibilitate asociată cu prima și cu cea de-a doua caracteristică. Așa cum am arătat în secțiunea anterioară, posibilitatea încorporării membrilor într-o categorie care nu corespunde sub toate aspectele definiționale cu membrii existenți are drept urmare faptul că trăsăturile care sunt enciclopedice (non-definiționale) în raport cu un set dat de membri se pot transforma în trăsături definiționale în raport cu un membru periferic al categoriei, încorporat în mod flexibil. Asemănarea dintre cazurile centrale și cele periferice se poate baza pe trăsăturile așa-zis enciclopedice la fel de bine cum se poate baza pe cele așa-zis „semantice”. Pe scurt, trăsături ale prototipicității care nu sunt incluse printre cele menționate la (i)-(iv) pot fi reduse adesea la cele patru, iar aceasta justifică în schimb o restricție preliminară a discuției privitoare la cea din urmă.

A doua observație cu privire la cele patru caracteristici privește faptul că ele sunt în mod sistematic relaționate pe două dimensiuni. Pe de o parte, a treia și a patra caracteristică iau în considerare structura referențială, extensională a unei categorii. Mai precis, ele privesc membrii unei categorii pentru a se evidenția că nu toți referenții unei categorii sunt egali în gradul de reprezentativitate pentru acea categorie și că granițele denotaționale ale unei categorii nu sunt întotdeauna clar delimitate. Pe de altă parte, aceste două aspecte (centralitatea şi non-rigiditatea) se repetă la nivel intensional, unde este luată în considerare mai degrabă structura definițională decît cea referențială a unei categorii. Mai întîi, non-rigiditatea se vede clar în faptul că nu există o singură definiție necesară și suficientă pentru un concept prototipic. Apoi, asemănările de familie implică suprapunerea subseturilor unei categorii. Adoptînd formularea din citatul introdus după (ii) dacă nu există o definiție care să descrie în mod corespunzător pe A, B, C, D și E, fiecare dintre subseturile $\mathrm{AB}, \mathrm{BC}, \mathrm{CD}$ și $\mathrm{DE}$ poate fi definit separat, dar, evident, sensurile astfel diferenţiate se suprapun. În consecință, sensurile ce prezintă un grad mai mare de suprapunere (în acest exemplu: sensurile ce corespund subseturilor BC și CD) vor avea o mai mare influență structurală decît înțelesurile care acoperă doar membrii periferici ai categoriei. Pe scurt, gruparea sensurilor, tipică pentru asemănările categoriale, presupune că nu orice membru este la fel de important din punct de vedere structural (și o observație asemănătoare poate fi făcută referitor la componentele în care aceste sensuri pot fi analizate). Conexiunile sistematice dintre caracteristicile menționate la început sunt redate schematic în Tabela 1.

Ca o a treia remarcă, ar trebui menţionat că cele patru caracteristici sunt deseori gîndite ca fiind coextensive, în ciuda unor atenționări izolate, dar clare, precum observația lui Rosch \& Mervis că o structură determinată de asemănările de familie nu trebuie să fie singura sursă a prototipicității $(1975$, p. 599). Adevărul este că e ușor să le considerăm ca fiind echivalente; în citatele oferite anterior deja pot fi descoperite unele dintre motivele interdependenței lor reciproce. Mai sistematic, următoarele asocieri între cele patru caracteristici ar putea fi răspunzătoare pentru ideea că prototipicitatea necesită prezența conjunctă a tuturor.

\begin{tabular}{lll}
\hline & $\begin{array}{l}\text { NON-EGALITATE } \\
\text { diferențe de dominanță structurală }\end{array}$ & $\begin{array}{l}\text { NON-RIGIDITATE } \\
\text { flexibilitate și ambiguitate }\end{array}$ \\
\hline EXTENSIONAL & grade ale reprezentativității & absența unor granițe precise \\
INTENSIONAL & fascicule de sensuri suprapuse & absența unei definiții clasice \\
\hline
\end{tabular}

Tabela 1: Caracteristici ale prototipicității

În primul rînd, corelarea primei caracteristici cu cea de-a doua reflectă raționamentul deja menționat: dacă nu există o singură definiție care să descrie suficient extensia unui obiect privit în ansamblu, atunci pot fi definite diferite subseturi, dar din moment ce membrii unei categorii pot fi de obicei grupați pe diferite dimensiuni, aceste subseturi au toate șansele să se suprapună, adică să formeze fascicule de sensuri înrudite.

În al doilea rînd, legătura dintre a doua și a treia caracteristică ține de ideea că membrii unei categorii care sunt întîlniţi pe o arie de suprapunere între două sensuri au mai multă influență structurală decît 
cazurile acoperite de un singur sens. Membrii reprezentativi ai unei categorii (adică situațiile cu un grad înalt de reprezentativitate) vor fi întîlniți pe suprafețele din extensia unei categorii suprapuse în cel mai mare grad. (În exemplul de față, A și E sunt membri mai puțin reprezentativi decît B, C și D, care țin de două subseturi diferite fiecare).

În al treilea rînd, asocierea dintre a treia și a patra caracteristică se referă la ideea că diferențele privind gradul de apartenență se pot diminua pînă într-un punct în care devine neclar dacă ceva mai aparține categoriei sau nu. Categoriile au limite estompate referențial ca urmare a statutului categorial ambiguu al elementelor cu grade de apartenență extrem de scăzute.

Și, în al patrulea rînd, corelarea celei de-a patra caracteristici cu prima reprezintă ideea că flexibilitatea, care este inerentă în absența unor limite clare, nu permite conceperea unei esențe comune tuturor membrilor categoriei. Pentru că este posibil ca elementele periferice să nu fie identice cu cele centrale, ci doar să împărtășească unele caracteristici cu acestea, este dificil de definit un set de atribute care să fie comun tuturor elementelor unei categorii și care să fie suficient pentru a diferenția categoria respectivă de toate celelalte.

Aceste legături circulare între cele patru caracteristici sunt, totuşi, eronate. O privire mai atentă asupra cîtorva exemple (familiare și mai puțin familiare) de prototipicitate arată că nu e nevoie ca ele să coexiste.

BIRD (PASĂRE)

Noțiunea bird „pasăre” (unul dintre primele exemple de prototipicitate oferite de Rosch) arată că pot exista granițe clar delimitate între categoriile naturale. Cel puțin în lumea noastră reală, denotarea lui bird „pasăre” este determinată; vorbitorii educaţi de limbă engleză știu foarte bine unde se termină păsările și unde încep non-păsările. Știu, de exemplu, că un liliac nu este pasăre, dar că un pinguin este. Desigur, nedeterminarea principială descrisă de Waismann (1952) ca „textură deschisă” se menține: confruntaţi cu o creatură SF (un mutant de după Cel de-al Treilea Război Mondial) care arată ca o pasăre, dar vorbește ca un om, nu am fi siguri dacă ar trebui să fie numită pasăre sau nu. În acel caz, ar apărea o problemă de demarcație, tipică pentru organizarea prototipică a vocabularului. Cu toate acestea, așa cum funcționează acum, în limba engleză actuală, bird este clar delimitat denotațional, dacă ignorăm arheopterixul ${ }^{14}$. Așa cum s-a observat în altă lucrare (Lakoff, 1987), existența efectelor prototipicității în concepte clar delimitate precum bird lasă să se înțeleagă că trebuie făcută o distincție netă între gradele de apartenență și cele de reprezentativitate. Apartenența la categoria bird este distinctivă; ceva este sau nu este o pasăre. Dar unele păsări pot fi mai păsări decît altele: rîndunica rămîne o pasăre mai reprezentativă decît struțul.

\section{RED (ROŞU)}

Termenii care denumesc culori, cum ar fi red „roșu” au constituit punctul de plecare al cercetării asupra prototipurilor; inspirîndu-se din opiniile dezvoltate în Berlin \& Kay (1969), prima lucrare a lui Rosch este o demonstrație experimentală a faptului că granița dintre diferite culori este imprecisă (nu există o singură linie în spectru unde roșu se oprește și începe portocaliu) și a faptului că fiecare termen care denumește culori este reprezentat psihologic prin culori centrale (unele nuanțe sunt resimțite ca tipuri mai relevante de roșu decît altele) (Heider, 1972; Heider \& Olivier, 1972). Aceste caracteristici prototipice la nivel extensiv nu au pereche la nivelul definiției. Dacă red poate fi definit cumva în mod analitic (adică dacă nu primește pur și simplu o definiție ostensivă constînd într-o enumerare a nuanțelor cu gradul lor de centralitate), definiția sa ar putea fi „având o culoare care este mai mult ca cea a sîngelui decît ca cea a unui cer lipsit de nori, a ierbii, a soarelui, a... (etc., enumerînd cîte un exemplar tipic pentru fiecare dintre celelalte culori principale)”. O astfel de definiție (cf. Wierzbicka, 1985, p. 342) nu corespunde nici primei, nici celei de-a doua caracteristici dintre cele menţionate anterior.

\footnotetext{
${ }^{14}$ Arheopterixul este probabil considerat atît o specie diferită de pasăre, cît și de reptilă.
} 
ODD NUMBER (NUMĂR IMPAR)

Armstrong et al. (1983) au demonstrat în mod experimental că pînă și un concept matematic precum odd number „număr impar” evidențiază efecte ale reprezentativităţii psihologice. Acest fapt poate părea incredibil, din moment ce odd number este un concept clasic în toate privințele: primește o definiție clară, nu prezintă o structură determinată de asemănările de familie sau de un set radial de sensuri grupate, nu are limite neclare. Cu toate acestea, Lakoff (1982) a precizat că existența gradelor reprezentativității în rîndul numerelor impare nu este surprinzătoare dacă este luată în considerare natura experiențială a reprezentărilor. De exemplu, caracterul par sau impar al unui număr mai amplu fiind determinat cu ușurință prin raportare la ultima cifră, nu este de mirare că numerele impare mai mici decît 10 au o mai mare influență psihologică: ele au o importanță majoră din punct de vedere procedural.

\section{VERS (FRESH / PROASPĂT)}

Așa cum am încercat să arăt cu altă ocazie (1988a), prima caracteristică menţionată anterior nu este suficientă pentru a distinge categoriile prototipice de cele clasice, din moment ce, în cadrul abordării clasice, absența unei definiții unice caracterizate prin necesitate și suficiență ar putea fi doar un indiciu al polisemiei. Aceasta înseamnă că trebuie arătat pe teren separat că presupusele concepte prototipice nu sunt polisemice sau înseamnă, mai degrabă, că noțiunile lexicale prototipice vor fi polisemantice potrivit unei analize definiționale, în termenii condițiilor necesare și suficiente (definiția clasică a polisemiei), dar univoce potrivit altor criterii. Aceste criterii se pot regăsi, de pildă, în intuițiile vorbitorilor nativi despre unitățile lexicale implicate, intuiții care pot fi descoperite prin teste precum cele ale lui Quine (1960) sau Zwicky \& Sadock (1975). În acest sens, prima caracteristică trebuie reformulată: categoriile prototipice vor oglindi nu doar absența unei definiții necesare şi suficiente, ci și univocitate intuitivă îmbinată cu polisemie analitică (definițională).

Odată ce această revizuire a primei caracteristici este acceptată, se poate demonstra că nu este necesar ca primul și al doilea criteriu să coexiste. Unităţile lexicale care ilustrează suprapuneri grupate de sensuri pot să se conformeze sau nu variantei revizuite a primei caracteristici. Un exemplu pentru prima situație este sensul literal al lui bird, un exemplu pentru a doua situație adjectivul olandez vers, care corespunde în linii mari englezescului fresh (cu excepția faptului că termenul olandez nu poartă sensul de „răcoros”). Detalii ale comparației dintre ambele categorii pot fi găsite în lucrarea menționată mai sus; rezumînd, Figurile 1 și 2 reprezintă analiza definițională a ambelor unităţi. Distincția intuitivă între vers și bird poate fi demonstrată prin intermediul testului quinean (în linii mari, o unitate lexicală este ambiguă dacă poate fi în mod simultan afirmată și negată de ceva într-un anumit context). Astfel, luînd un exemplu bazat pe respectiva ambiguitate în echivalentul englezesc al lui vers, ar fi destul de normal să susținem că știrea la care se referă enunțul there was no fresh news from the fighting [nu era nici o știre proaspătă de la luptă ${ }^{15}$ este proaspătă într-un sens („,recentă, nouă”), dar nu și în altul (,în stare optimă”): este logic să spunem că, în acelaşi timp, vestea este și nu este proaspătă. Pe de altă parte, ar fi în mod intuitiv paradoxal să afirmăm că un pinguin este și nu este pasăre în același timp (ignorînd extensiile figurate din aria semantică a lui pasăre). Cu toate acestea, analizele definiționale din Figurile 1 and 2 arată clar că ambele concepte prezintă grupare prototipică. De asemenea, în ambele cazuri, poziția structurală a cazurilor discutate (veste, pinguin) nu se află în zona centrală cu suprapunere maximă. Pe scurt, aşadar, versiunea revizuită a primei caracteristici nu coincide în mod necesar cu cea de-a doua caracteristică.

Observațiile ce reies dintr-o examinare mai atentă a celor patru exemple tocmai descrise pot fi rezumate ca în Tabela 2. Este ușor acum să vedem în ce măsură 'prototipicitatea' este ea însăși o noțiune prototipică. Nu există un set unic de atribute care să fie comun tuturor exemplelor discutate aici. Ele prezintă, mai degrabă, o structură determinată de asemănarea de familie, bazată pe similitudini parțiale. În acest sens, setul conceptelor prototipice caracterizat prin gruparea sensurilor se suprapune cu subsetul caracterizat prin

\footnotetext{
${ }^{15}$ Exemplul este preluat din Longman Dictionary of Contemporary English.
} 


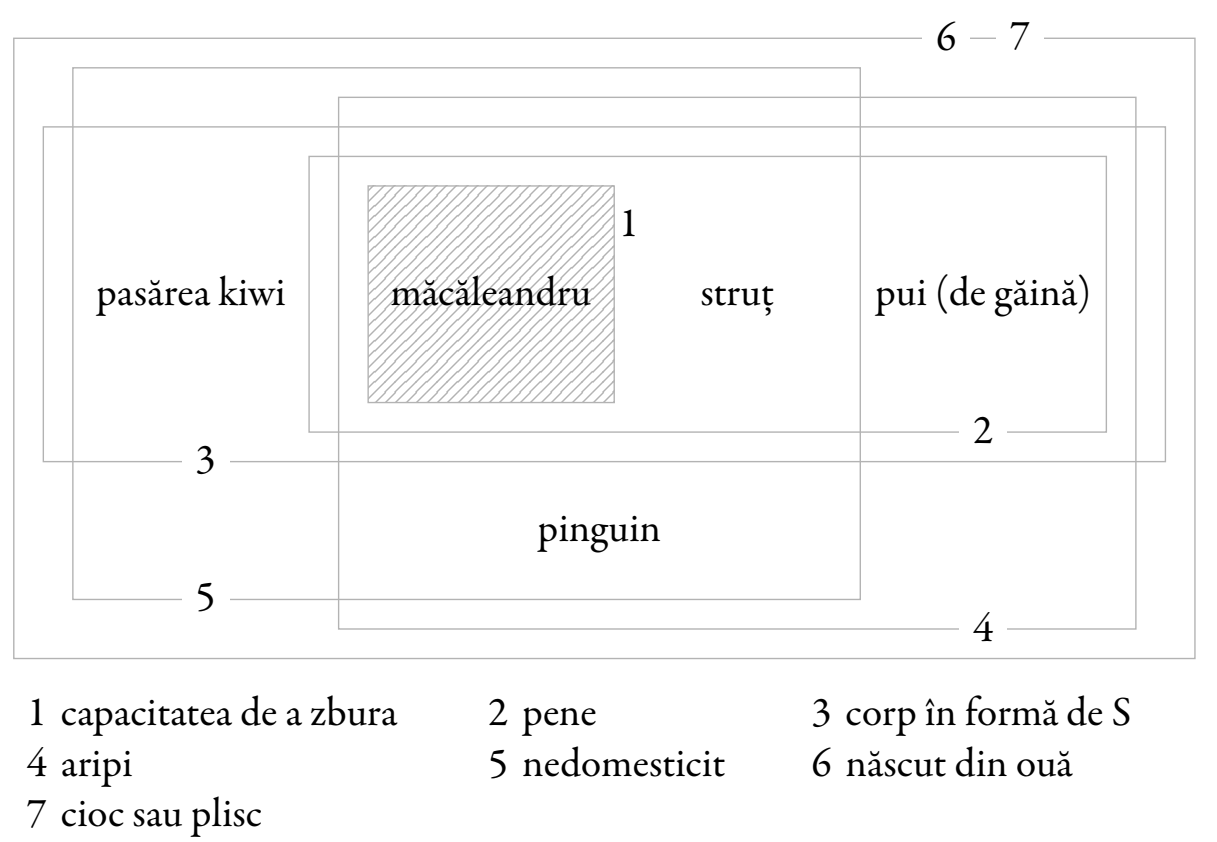

Figura 1: $\mathrm{O}$ analiză definițională a lui bird

limite neclare (din cauza lui vers), și așa mai departe. În același timp, unele concepte sînt mai reprezentativ prototipice decît altele. (Bird și vers sînt mai prototipice decît $r e d$ ). Observați, mai ales, cum categoria fruit "fruct” reprezintă un bun candidat pentru prototipicitatea prototipică, în sensul că pare să îmbine toate cele patru caracteristici. Împărtășește trăsăturile prototipice ale lui bird „pasăre”, dar, în plus, elemente precum nuci de cocos și, probabil, roșii par să indice că limita denotației lui fruit „fruct” este mai slab definită decît cea a lui bird.

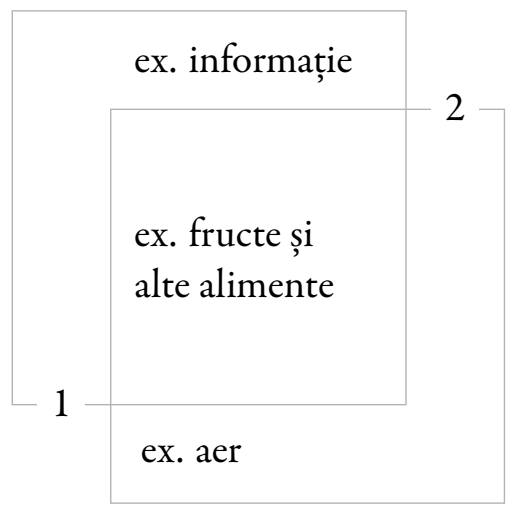

1 nou, inedit, recent

2 în stare optimă, pur, nealterat

Figura 2: O analiză definițională a lui vers

Totuși, deși exemplele discutate mai sus nu au în comun un set de atribute, ele au o trăsătură comună, și anume existența gradelor de reprezentativitate a membrilor. Este incert, totuși, dacă doar această trăsătură este suficientă pentru a distinge conceptele prototipice de conceptele clasice. Dacă posibilitatea unei definiții unice necesare și suficiente reprezintă una dintre trăsăturile prin excelență cu care concepția clasică s-a identificat, s-ar putea susţine în mod justificat că ierarhizarea reprezentativității este pe deplin compatibilă cu concepția clasică a categorizării. De fapt, acesta este sensul în care Armstrong et al. (1983) s-au ocupat 
de o categorie precum cea a lui odd number. Experimentele utilizate de Rosch pentru a măsura gradele de reprezentativitate nu sînt, spun ei, elocvente pentru prototipicitate, din moment ce apar în cazul unor concepte clasice, inflexibil definibile, precum odd number. Ca să spunem așa, efectele reprezentativității constituie doar un atribut prototipic periferic, potrivit Tabelei 2 (cf. Lakoff, 1986). În același timp însă, disputa privind statutul lui odd number demonstrează că noțiunea de 'concept prototipic' nu are granițe precise: nu este în mod direct limpede dacă un concept precum odd number ar trebui inclus în setul conceptelor prototipice sau nu.

\begin{tabular}{|c|c|c|c|c|}
\hline & 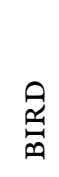 & $\frac{\mathscr{n}}{\stackrel{n}{r}}$ & 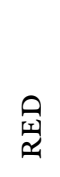 & 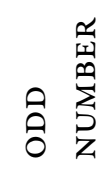 \\
\hline absența unei definiții clasice & + & - & - & - \\
\hline fascicule de sensuri suprapuse & + & + & - & - \\
\hline grade ale reprezentativității & + & + & + & + \\
\hline absența limitelor clare & - & + & + & - \\
\hline
\end{tabular}

Tabela 2: Prototipicitatea 'prototipicității'

Desigur, contrar situației din vorbirea cotidiană, o asemenea controversă asupra limitelor nu ar trebui să se mențină în discursul științific. O disciplină ca lingvistica ar trebui să încerce să își definească cît mai clar conceptele, iar scopul acestei secțiuni este tocmai acela de a arăta că ceea ce a fost în mod intuitiv clasificat ca exemplificare a categoriilor prototipice constă în fenomene distincte ce trebuie separate din punct de vedere teoretic. Totuși, în concordanță cu înşăși teoria prototipului, o asemenea încercare de definire clară nu ar trebui să presupună o încercare de a defini „adevărata natură” sau ,însăși esența” prototipicităţii. A determina „un singur tip adevărat” de prototipicitate este infinit mai puțin important decît a vedea care sunt fenomenele și cum sunt ele interelaționate prin deosebiri sau asemănări.

Totuși, s-ar părea că există o cale prin care s-ar putea înțelege destul de bine care este adevăratul sens al prototipicității. Pentru început, să observăm că natura prototipică atribuită conceptului de prototipicitate este pusă în evidență și prin faptul că noțiunea 'prototip' este extrem de flexibilă. Acest fapt poate fi ilustrat în două moduri. În primul rînd, unitatea lexicală prototipic este utilizată spontan pentru a numi un număr de fenomene legate prin metonimie, alături de fenomenele de similitudine reunite în Tabela 2. Elementul lexical nu descrie doar trăsăturile structurale ale conceptelor sau chiar conceptele care prezintă acele trăsături, ci uneori chiar instanțe particulare (adică puternic reprezentative) ale categoriilor în discuție (măcăleandrul ca pasăre prototipică). În al doilea rînd, contextul poate pune mai bine în valoare o trăsătură a organizării prototipice decît alta (cf. efectele de amorsare în Rosch, 1975). Scopul general al investigațiilor unui individ îl poate conduce pe acesta să dedice mai multă atenție unui aspect al grupului prototipic decît altuia. Să menționăm cîteva exemple: gradele de reprezentativitate sînt importante pentru studiile privind dezvoltarea limbii (dacă se ia în considerare că cele mai multe concepte din dezvoltarea incipientă a limbii sunt obținute prin intermediul exemplarelor lor), în timp ce gruparea suprapunerilor de sensuri se remarcă în studiile lingvistice sau lexicografice privind structura polisemiei. Iar interesul cognitiv față de principiile epistemologice care stau la baza limbajului natural va acorda o importanță sporită separării dintre univocitatea intuitivă și polisemia definițională, analitică ${ }^{16}$.

În acest sens, nelămurirea legată de adevărata natură a prototipicității s-ar putea transforma într-o problemă care ar putea oferi cea mai interesantă (sau poate chiar cea mai importantă) perspectivă în studiul şi definirea prototipicităţii. Însă, din nou, „eroarea de fond fundamentală” expusă de însăşi teoria prototipului pîndește de după colț: vor exista diferite preferințe pentru o perspectivă în detrimentul alteia și nu

\footnotetext{
${ }^{16}$ Judecate din acest punct de vedere, seturile radiale ale lui Lakoff nu sunt, ca atare, extrem de „neclasice”: polisemia structurată propriu-zisă este pe deplin compatibilă cu viziunea clasică. Kleiber (1988) propune o discuţie pătrunzătoare a consecințelor pe care importanța crescîndă acordată structurii polisemiei o are în cercetarea teoretică a prototipurilor.
} 
va exista doar o singură concepție asupra prototipicității care să fie în cele din urmă și pentru totdeauna cea mai importantă.

Pe scurt, analiza anterioară coroborează afirmația lui Wierzbicka că există „multe înțelesuri” atribuite noțiunii prototip cu aceea că „,noțiunea de prototip a fost utilizată în literatura recentă ca o noțiune atotcuprinzătoare” (1985, p. 343). Totuşi, o analiză mai sistematică decît cea întreprinsă de Wierzbicka arată că această varietate extremă a întrebuințărilor stă, de asemenea, în sprijinul semanticii cognitive, în sensul în care arată că aceleași principii ale categorizării pot ghida judecata comună și gîndirea științifică. Acesta este, așadar, încă un indiciu al relevanței metateoretice a unei concepții cognitive asupra categorizării lingvistice, aspect studiat pe larg în altă lucrare (1985b). În acelaşi timp, a devenit clar că una dintre temele majore ale dezvoltării ulterioare a teoriei prototipului este cercetarea mai atentă a trăsăturilor prototipice fasciculare ale prototipicităţii. O referință importantă în acest sens este încercarea lui Lakoff (1987, Capitolele 4-8) de a determina ce tipuri diferite de modele conceptuale pot sta la baza efectelor de prototipicitate.

\section{Probleme de definire, seria a doua: 'teoria prototipului' ca noțiune prototipică}

Dacă secțiunea anterioară a clarificat faptul că prototipicitatea, aşa cum este ea utilizată în semantica lingvistică, este un concept structurat prototipic, ar trebui observat acum că mișcarea teoretică a prototipului este și ea o abordare semantică structurată prototipic. Există, cu alte cuvinte, exemple centrale, dar și mai periferice, de teorii prototipice. Mai exact, există o serie de teorii care îmbină aspecte ale abordării clasice a structurii semantice cu aspecte ale concepției prototipice. În această secțiune, vor fi discutate două abordări care sunt într-o anumită măsură semi-clasice, precum și semi-prototipice; fiecare întruchipează o strategie de repunere în drepturi a anumitor aspecte ale viziunii clasice în pofida contextului unui punct de vedere în general cognitivist.

Pentru început, o parte din claritatea și ordinea abordării clasice poate fi recuperată prin concentrarea asupra centrului prototipic al unei categorii. Dacă nedeterminarea non-clasică a conceptelor lexicale își are originea în primul rînd în extensibilitatea flexibilă a reprezentărilor, caracterul discret poate fi restabilit prin evitarea problemelor de polisemie, adică prin limitarea analizei definiționale la centrul prototipic al categoriei. Această abordare este viguros sprijinită de Wierzbicka (1985), care apără în mod explicit natura discretă a semanticii, luînd introspectiv în considerare doar centrul clar, salient al categoriilor lexicale. Întro expunere a investigației experimentale pe care a întreprins-o Labov asupra caracteristicilor non-clasice ale conceptelor cotidiene (1973), ea observă ${ }^{17}$ :

Pentru a stabili sensul unui cuvînt, nu este suficient să studiem aplicabilitatea acestuia la lucruri; ceea ce trebuie să facem mai presus de toate este să studiem structura conceptului, care fundamentează și explică acea aplicabilitate. În cazul cuvintelor care descriu categorii naturale sau tipuri de artefacte umane, a înțelege structura conceptului înseamnă a descrie complet și exact ideea (nu doar imaginea vizuală) a reprezentantului tipic al categoriei: prototipul. Iar pentru a o descrie complet și exact trebuie să descoperim logica internă a conceptului. Aceasta se face cel mai bine nu prin interviuri, nu prin experimente de laborator și nu prin comunicarea unor impresii sau intuiții cotidiene, superficiale... ci prin introspecție și gîndire metodică (Wierzbicka, 1985, p. 19).

Ar trebui observat imediat că restaurarea de către Wierzbicka a caracterului discret nu presupune că definiţiile date de ea se compun întotdeauna din condiții necesare și suficiente, iar aceasta o recunoaște chiar autoarea (1985, p. 60). În acest sens, abordarea propusă de Wierzbicka este doar într-o anumită măsură o abatere de la solidele studii teoretice ale prototipului: absența condițiilor necesare și suficiente din definirea unor concepte centrale este acceptată, dar evitarea problemei polisemiei grupate „face ordine” în descrierea semantică și reafirmă o anumită claritate clasică. Abordarea propusă de Wierzbicka nici nu

\footnotetext{
${ }^{17}$ Pentru o discuție mai detaliată a opiniilor înaintate de Wierzbicka, vezi Geeraerts (1988d).
} 
lasă să se înțeleagă că unitățile lexicale ar fi întotdeauna univoce; în dicționarul ei de verbe englezești ale spunerii (1987), unele elemente primesc definiţii multiple. Totuși, fiecare dintre definiții reflectă întradevăr o semnificație dominantă și, din nou, prin ignorarea tipurilor periferice de utilizare se scoate din schemă structura grupată sau radială a polisemiei unităților lexicale. Întrebarea care trebuie pusă, aşadar, este dacă limitarea descrierii la semnificațiile saliente ale unei categorii este utilă și potrivită din unghi cognitivist.

Din punct de vedere metodologic, periferia categoriilor naturale, definibile în moduri multiple, este la fel de interesantă ca și centrul (centrele) salient (e) al(e) acestora, pentru că tocmai relația dintre cele două este cea care descrie în mod tipic categoriile naturale. Lingvistica cognitivă nu se axează doar asupra a ceea ce constituie centrul unei categorii, ci și asupra modului în care acest centru se poate extinde spre cazurile periferice și de cît de departe poate ajunge această extensie. Mecanismele de încorporare a cazurilor marginale într-o categorie limitează în același timp flexibilitatea acelui concept; doar studiind cazurile periferice se poate găsi un răspuns referitor la întrebarea despre cît de diferite pot fi lucrurile înainte ca ele să nu mai fie recunoscute ca fiind, în fond, aceleași. Cu alte cuvinte, dacă polisemantizarea flexibilă este într-adevăr una dintre caracteristicile majore ale categoriilor limbii naturale, o limitare intenționată a descrierii la sensurile saliente ale unei categorii este mai puțin favorabilă din punct de vedere metodologic, din moment ce poate conduce la o neglijarea acestei trăsături esențiale ${ }^{18}$.

$\mathrm{O}$ a doua strategie pentru recuperarea unor aspecte din abordarea clasică este aceea de a invoca mecanisme sociolingvistice precum „diviziunea muncii lingvistice” formulată de Putnam (1975). După Putnam, utilizatorii limbii comune nu posedă decît cunoștințe „stereotipice” despre categoriile naturale, adică sînt conștienți de un set de caracteristici dominante, cum ar fi faptul că apa este un lichid transparent, insipid, care potolește setea. Cu toate acestea, definiția tehnică a apei ca $\mathrm{H}_{2} \mathrm{O}$ ține de câmpul științei. Cunoașterea experților este cea care decide în cele din urmă cum trebuie utilizați termenii unei categorii naturale. Pe de o parte, o „diviziune a muncii lingvistice” garantează că există experți sociali care știu că apa este $\mathrm{H}_{2} \mathrm{O}$, că există o distincție între ulm și fag, că aurul se deosebește de pirită și așa mai departe. Pe de altă parte, nespecialiștii își acomodează propriul uz lingvistic după cel al oamenilor de știință, al tehnicienilor etc. Membrilor grupului nespecialzat nu li se cere să dețină cunoștințe la nivel de expert, dar dacă își doresc să fie consideraţi membri cu drepturi depline ai comunităţii lingvistice, ar trebui să cunoască „stereotipul” asociat unei categorii. Un stereotip este un set minim, determinat social, de informații referitoare la extensia unei categorii. Dată fiind asemănarea dintre stereotipurile lui Putnam și prototipurile lingvisticii cognitive (ambele constau, în general, în cele mai proeminente informații asociate unei categorii), diviziunea muncii lingvistice ar putea fi utilizată pentru a recupera viziunea clasică asupra conceptelor ${ }^{19}$. Definițiile specializate fiind clasice (indică o „structură ascunsă” de tip esenţialist a categoriilor naturale), cu greu s-ar putea ca noțiunile stereotipice ale vorbitorilor obișnuiți să fie considerate superioare unui derivat decăzut al acelor categorii specializate, definite în mod clasic. Definițiile „adevărate” (specializate) ar fi clasice, iar conceptele stereotipice/prototipice ar putea fi scoase din prim-plan ca fenomene secundare din punct de vedere sociolingvistic.

Ar trebui observat neîntîrziat că o astfel de restabilire a viziunii clasice nu este la fel de relevantă pentru

\footnotetext{
${ }^{18}$ A se observa că limitarea la centrul prototipic al categoriilor are legătură cu metodologia introspectivă, platoniciană susţinută de Wierzbicka: pare probabil ca aplicațiile unei categorii care pot fi accesate introspectiv să fie doar cele mai saliente; cazurile periferice probabil nu trec întotdeauna pragul atenției conștiente. Cu toate acestea, ceea ce este interesant din unghi cognitivist este modul în care oamenii categorizează și clasifică spontan lucrurile, nu modul în care ei reflectă introspectiv asupra propriilor conceptualizări. Orice încercare de a descrie instanțele periferice ale unei categorii alături de centrul prototipic al acesteia poate așadar să nu fie restrînsă la o metodologie introspectivă.

${ }^{19}$ Asta nu înseamnă că Putnam și-a gîndit în realitate teoria stereotipică ca pe o astfel de recuperare intenționată; problemele lui se situează mai degrabă în raport cu noțiunea de referință decît cu cele de polisemie și structură categorială. Comentariile mele despre Putnam reprezintă o investigație a cîtorva dintre consecințele posibile ale noțiunii de diviziune a muncii lingvistice, nu o încercare de a oferi o imagine a viziunii lui Putnam în forma sa inițială. Mai mult, trebuie menționat fapul că unele dintre concepțiile filosofice ulterioare ale lui Putnam dezvăluie perspective complet diferite pentru o confruntare cu semantica cognitivă; a se vedea în special lucrarea lui Lakoff (1987) despre Putnam și anti-obiectivism.
} 
alte cuvinte decît termenii ce denumesc categorii naturale, cărora teoria lui Putnam le este de fapt destinată. (Care este definiția savantă pentru prepoziția pentru?). Mai mult decît atît, ca teorie sociolingvistică privind factorii sociali care determină modul în care unitățile lexicale pot fi utilizate, teoria „diviziunii muncii lingvistice” este cel puțin incompletă. Primatul definiției specializate ar părea să sugereze că limba naturală urmărește dezvoltările și descoperirile științei într-un mod absolut. Cu toate acestea, în realitate, categorizarea nu este în limba naturală determinată doar de starea lucrurilor din științe, ci și de exigențele cognitive și comunicative ale comunității lingvistice propriu-zise. Chiar unul dintre exemplele lui Putnam poate servi ca demonstrație. Chiar dacă știința a stabilit că jad trimite la două tipuri de material (unul cu „structura ascunsă” a silicatului de calciu și magneziu, celălalt fiind un silicat de sodiu și aluminiu), uzul obișnuit continuă să se refere fără deosebire la ambele substanțe prin jad. Cu alte cuvinte, categorizarea în limba obișnuită nu depinde în întregime de cercetările științifice, ci pare să fie determinată măcar parțial de criterii independente: dacă exigențele clasificatoare din interacțiunea comunicativă cotidiană nu reclamă o distincție între cele două tipuri de jad, scindarea științifică a categoriei este în mare parte ignorată. Aceasta presupune că este justificată investigarea categorizării în limba de uz cotidian ca sistem cognitiv independent. În ansamblu, dacă perspectiva propusă de Putnam este considerată ca o teorie referitoare la structura sociolingvistică a normelor semantice, modelul ei ierarhic (cu specialişti la un capăt și nespecialiști la celălalt) reprezintă doar una dintr-o serie de alternative, dintre care unele (ca cea descrisă de Bartsch, 1985) se leagă îndeaproape de o concepție prototipică asupra structurii categoriale. În același timp, ar trebui totuși acceptat că relația dintre categorizarea științifică clasică și categorizarea prototipică practică poate fi cercetată mai în profunzime decît este cazul deocamdată ${ }^{20}$.

Pe scurt, confuzia asociată noțiunii de prototipicitate este sporită și mai mult de faptul că abordările mai direct prototipice sunt înconjurate de teorii hibride care conțin anumite strategii de a combina caracterul discret clasic cu fenomenele în mod reprezentativ prototipice. Am discutat două astfel de abordări (una în care strategia în discuție este metodologică și alta în care aceasta este sociolingvistică), dar asta nu înseamnă că acestea sînt singurele care ar putea fi menționate ${ }^{21}$. Totuşi, cele două abordări amintite aici sînt deosebit de semnificative, din moment ce ele se leagă de două curente importante din istoria gîndirii occidentale. Prima dintre ele se reduce, prin simplificare, la viziunea că mintea umană este organizată (dacă o examinezi cu destulă atenție), dar lumea este ambiguă: caracterul non-discret cu care se ocupă lingvistica cognitivă decurge din faptul că trebuie să aplicăm categorii cognitive bine definite unei realități exterioare care nu este, ca să zicem așa, tot atît de bine organizată. Concepția conform căreia lumea entităților cognitive este cumva mai bine organizată decît lumea din afară este în mod evident una idealistă (deși nu constituie singurul tip posibil de idealism); Wierzbicka însăși pune accentul pe caracterul platonician al abordării sale. Pe de altă parte, opinia formulată de Putnam potrivit căruia știința este organizată, în vreme ce limba obişnuită este neclară se leagă de obiectivismul ramurii limbii ideale din filosofia analitică: structura obiectivă a realității este cel mai bine descrisă de limba științei, iar limba obișnuită reprezintă în cel mai bun caz un derivat slab al categorizării științifice, în cel mai rău caz o confuzie conceptuală în care pseudo-problemele filozofice abundă. Dacă am semnalat deja că lingvistica cognitivă intransigentă evită atît opțiunea idealistă, cît și pe cea obiectivistă, avem aici încă un semn ${ }^{22}$ al necesității de a continua cercetările privind contextul epistemologic, filosofic al concepției prototipice asupra structurii categoriale.

\footnotetext{
${ }^{20}$ O contribuție interesantă la o astefel de cercetare se găsește în Lakoff (1987, Capitolul 12), unde se susține că categoriile științifice sunt departe de a fi atît de clasice precum se presupune în mod obișnuit.

${ }^{21}$ Din nou, a se vedea Lakoff (1987, Capitolul 9) pentru alte cîteva exemple; ele sînt situate mai degrabă în cadrul psiholexicologiei formale decît în cadrul lingvisticii.

22 Adică pe lîngă comentariile din nota 13 .
} 


\section{Bibliography}

Aijmer, K. (1985). The semantic development of will, în J. Fisiak (ed.), Historical Semantics - Historical Word-Formation, Mouton de Gruyter, Berlin / New York, p. 11-21.

Armstrong, S.L., Gleitman, L.R. \& Gleitman, H. (1983). What some concepts might not be, în „Cognition”, vol. 13, nr. 3, p. 263-308, Crossref.

Bartsch, R. (1985). Sprachnormen: Theorie und Praxis, Niemeyer Verlag, Tübingen <prospects>.

Berlin, B. \& Kay, P. (1969). Basic Color Terms, University of California Press, Berkeley.

Bybee, J. \& Moder, C.L. (1983). Morphological classes as natural categories, în „Language”, vol. 59, nr. 2, p. 251-270, Crossref. Coleman, L. \& Kay, P. (1981). Prototype semantics: the English word lie, în „Language”, vol. 57, nr. 1, p. 26-44, Crossref.

Craig, C. (ed.) (1986). Noun Classes and Categorization, John Benjamins Publishing Company, Amsterdam / Philadelphia, Crossref.

Dirven, R. (1988). Bibliography of Cognitive Linguistics, Linguistic Agency of the University of Duisburg, Duisburg.

Dowty, D. (1979). Word meaning and Montague Grammar, Reidel, Dordrecht.

Fillmore, C.J. (1975). An alternative to checklist theories of meaning, în C. Cogen, H. Thompson \& J. Wright (eds), Proceedings of the First Annual Meeting of the Berkeley Linguistics Society, Berkeley Linguistics Society, p. 123-131.

Fillmore, C.J. (1977). Scenes-and-frames semantics, în A. Zampolli (ed.), Linguistic Structures Processing, North Holland Publishing Company, Amsterdam, p. 55-81.

Geeraerts, D. (1983). Prototype theory and diachronic semantics: a case study, în „Indogermanische Forschungen”, nr. 88, p.132.

Geeraerts, D. (1985a). Paradigm and Paradox. Explorations into a Paradigmatic Theory of Meaning and its Epistemological Background, Universitaire Pers, Leuven.

Geeraerts, D. (1985b). Les données stéréotypiques, prototypiques et encyclopédiques dans le dictionnaire, in „Cahiers de Lexicologie", nr. 46, p. 27-43.

Geeraerts, D. (1985c). Cognitive restrictions on the structure of semantic change, în J. Fisiak (ed.), Historical Semantics - Historical Word Formation, Mouton de Gruyter, Berlin / New York, p. 127-153.

Geeraerts, D. (1988a). Cognitive Grammar and the History of Lexical Semantics, în B. Rudzka-Ostyn (ed.), Topics in Cognitive Linguistics, John Benjamins Publishing Company, Amsterdam / Philadelphia, p. 647-677.

Geeraerts, D. (1988b). Katz revisited: aspects of the history of lexical semantics, în W. Hiillen \& R. Schulze (eds), Understanding the Lexicon, Max Niemeyer Verlag, Tübingen, p. 23-35.

Geeraerts, D. (1988c). Review of Anna Wierzbicka, Lexicography and Conceptual Analysis, în „Language in Society”, vol. 17, nr. 3, p. 449-455, Crossref.

Geeraerts, D. (1988d). Where does prototypicality come from?, în B. Rudzka-Ostyn (ed.), Topics in Cognitive Linguistics, John Benjamins, Amsterdam / Philadelphia, p. 207-229.

Givón, T. (1986). Prototypes: between Plato and Wittgenstein, în Craig, 1986, p. 78-102, Crossref.

Haimann, J. (1980). Dictionaries and encyclopedias, în „Lingua”, vol. 50, nr. 4, p. 329-357, Crossref.

Heider, E. R. (1972). Universals in color naming and memory, în „Journal of Experimental Psychology”, vol. 93, nr. 1, p. 10-20.

Heider, E.R. \& Olivier, D.C. (1972). The structure of color space in naming and memory for two languages, in "Cognitive Psychology”, vol. 3, nr. 2, p. 337-354, Crossref.

Holland, D. \& Quinn, N. (eds.) (1987). Cultural Models in Language and Thought, Cambridge University Press, Cambridge, Crossref.

Hüllen, W. \& Schulze, R. (eds.) (1988). Understanding the Lexicon. Meaning, Sense, and World Knowledge in Lexical Semantics, Max Niemeyer Verlag, Tübingen.

Katz, J.J. \& Fodor, J.A. (1963). The structure of a semantic theory, în „Language”, vol. 39, nr. 2, p. 170-210, Crossref.

Kleiber, G. (1988). Prototype, stéréotype: un air de famille?, în „DRLA V Revue de Linguistique”, vol. 38, p. 1-61.

Labov, W. (1973). The boundaries of words and their meanings, în Charles J. Bailey \& Roger Shuy (eds.), New Ways of Analysing Variation in English, Georgetown University Press, Washington, p. 340-373.

Lakoff, G. (1982). Categories and cognitive models, Linguistic Agency of the University of Trier, Trier; also as Berkeley Cognitive Science Report no. 2 (Berkeley, Institute for Human Learning).

Lakoff, G. (1986). Classifiers as a reflection of mind, în Craig, 1986, p. 13-51, Crossref.

Lakoff, G. (1987). Women, Fire, and Dangerous Things. What Categories Reveal about the Mind, University of Chicago Press, Chicago, IL.

Langacker, R. W. (1987). Foundations of Cognitive Grammar I, Stanford University Press.

Lehmann, W.P. (ed.) (1988). Prototypes in Language and Cognition, Karoma, Ann Arbor.

Medin, D.L. \& Smith, E.E. (1984). Concepts and concept formation, în „Annual Review of Psychology”, vol. 35, p. 113-138, Crossref.

Mervis, C.B. \& Rosch, E. (1981). Categorization of natural objects, în „Annual Review of Psychology”, nr. 32, p. 89-115, Crossref. 
Nathan, G.S. (1986). Phonemes as mental categories, în V. Nikiforidou, M. VanClay, M. Niepokuj, D. Feder (eds.), Proceedings of the Twelfth Annual Meeting of the Berkeley Linguistics Society, Berkeley Linguistics Society, p. 212-224.

Neisser, U. (1987). Concepts and Conceptual Development. Ecological and Intellectual Factors in Categorization, Cambridge University Press.

Posner, M. (1986). Empirical studies of prototypes, în Craig, 1986, p. 53-61, Crossref.

Post, M. (1986). A prototype approach to denominal adjectives, în D. Kastovsky \& A. Szwedek (eds.), Linguistics across Historical and Geographical Boundaries, II, Mouton De Gruyter, Berlin - New York, p. 1003-1013.

Putnam, H. (1975). The meaning of Meaning, în H. Putnam, Mind, Language, and Reality. Philosophical Papers II, Cambridge University Press, p. 215-271.

Quine, W.V.O. (1960). Word and Object, MIT Press, Cambridge, MA.

Reichling, A. (1935). Het Woord, Tjeenk Willink, Zwolle.

Rosch, E. (1973). On the internal structure of perceptual and semantic categories, în T.E. Moore (ed.), Cognitive Development and the Acquisition of Language, Academic Press, New York, p. 111-144.

Rosch, E. (1975). Cognitive representations of semantic categories, în „Journal of Experimental Psychology: General”, vol. 104, nr. 3, p. 192-233, Crossref.

Rosch, E. (1977). Human categorization, în N. Warren (ed.), Studies in Cross-cultural Psychology I, Academic Press, New York, p. 1-49.

Rosch, E. (1978). Principles of categorization, în E. Rosch \& B. B. Lloyd (eds.), Cognition and Categorization, Lawrence Erlbaum, Hillsdale, NJ, p. 27-48.

Rosch, E. (1988). Coherences and categorization: a historical view, în F. Kessel (ed.), The Development of Language and Language Researchers. Essays in Honor of Roger Brown, Lawrence Erlbaum, Hillsdale, NJ, p. 373-392.

Rosch, E. \& Mervis, C. B. (1975). Family resemblances: Studies in the internal structure of categories, în „Cognitive Psychology”, vol. 7, nr. 4, p. 573-605, Crossref.

Rosch, E., Mervis, C. B., Gray, W.D., Johnson, D. \& Boyes-Braem, P. (1976). Basic objects in natural categories, în „Cognitive Psychology”, vol. 8, nr. 3, p. 382-439, Crossref.

Rosch, E., Simpson, C. \& Miller, S.R. (1976). Structural bases of typicality effects, în „Journal of Experimental Psychology: Human Perception and Peformance”, vol. 2, nr. 4, p. 491-502, Crossref.

Ross, J. R. (1987). Islands and syntactic prototypes, în B. Need, E. Schiller \& A. Bosch (eds.), Papers from the 23rd Annual Meeting of the Chicago Linguistic Society, Chicago Linguistic Society, p. 309-320.

Rudzka-Ostyn, B. (1988). Semantic extensions into the domain of verbal communication, în B. Rudzka-Ostyn (ed.), Topics in Cognitive Linguistics, John Benjamins Publishing Company, Amsterdam - Philadelphia, p. 507-553.

Seiler, H. (1986). Apprehension: Language, Object, and Order, Gunter Narr Verlag, Tübingen.

Smith, E. \& Medin, D. (1981). Categories and Concepts, Harvard University Press, Cambridge, MA.

Taylor, J. (1989). Linguistic Categorization. Prototypes in Linguistic Theory, Clarendon Press, Oxford.

Tsohatzidis, S.L. (ed.) (1989). Meanings and Prototypes. Studies on Linguistic Categorization, Routledge and Kegan Paul, London.

Uhlenbeck, E. M. (1967). The dynamic nature of word meaning, în Actes du Xe Congrès International des Linguistes II, Editions de l'Academie, Bucureşti, p. 679-685.

van Langendonck, W. (1986). Markedness, prototypes, and language acquisition, în „Cahiers de l'Institut de Linguistique de Louvain", nr. 12, p. 39-76.

van Oosten, J. (1986). The nature of subjects, topics, and agents: a cognitive explanation, Indiana University Linguistics Club, Bloomington.

Waismann, F. (1952). Verifiability, în A. Flew (ed.), Logic and Language (First Series), Basil Blackwell, Oxford, p. $117-144$.

Weinreich, U. (1966). Explorations in semantic theory, în Current trends in linguistics III, p. 395-479.

Wierzbicka, A. (1985). Lexicography and Conceptual Analysis, Karoma, Ann Arbor, MI.

Wierzbicka, A. (1987). English speech act verbs: a semantic dictionary, Academic Press, Sydney.

Winters, M. (1987). Syntactic and semantic space: the development of the French subjunctive, în A. G. Ramat, O. Carruba \& G. Bernini (eds.), Papers from the 7th International Conference on Historical Linguistics, John Benjamins Publishing Company, Amsterdam - Philadelphia, p. 607-618, Crossref.

Wittgenstein, L. (1953). Philosophische Untersuchungen. Philosophical Investigations, Basil Blackwell, Oxford.

Zwicky, A. \& Sadock, J. (1975). Ambiguity tests and how to fail them, în J. Kimball (ed.), Syntax and Semantics 4, Academic Press, New York, p. 1-36.

[Traducere de Gabriela-Iuliana Morcov și Ioan Milică] 